\title{
A Comparative Analysis of Job Satisfaction Among Public and Private Sector College / University \\ Teachers in Lahore
}

\section{Aamir Ali Chughtai"}

\section{Background \& Objectives}

A high quality teaching staff is the cornerstone of a successful education system. Daily interaction between teachers and students is at the center of the educational process. Attracting and retaining high quality teachers is thus a primary necessity for a strong education system. One step in developing a high quality faculty is to understand the factors associated with teaching quality and retention. One of these factors is job satisfaction. Very often, it is not merely satisfaction with the job, but with the career in general, that is important. With teachers, satisfaction with their careers may have strong implications for student learning. Specifically, a teacher's satisfaction with his or her career may influence the quality and stability of instruction given to the students. Some researchers argue that teachers who do not feel supported in their work may be less motivated to do their best work in the class- room (Ostroff, 1992; \& Ashton \& Web, 1986). This would ultimately have an adverse impact on student achievement. In addition, highly satisfied teachers are less likely to leave the teaching profession altogether than those who are dissatisfied with many areas of their work life (Choy et al., 1993). Such departures disrupt the education system and result in the shift of valuable educational resources away from actual instruction towards costly staff replacement efforts. It is not necessary to be a management expert or an economist to understand that if the education managers are spending thousands of rupees and hours of their time to replace teachers who have left, preventing the brain drain in the first place might have saved some of those resources. Because faculty are both the largest cost and the largest human capital resource of an education system, understanding factors that contribute to teacher satisfaction (or dissatisfaction) is essential to improving the information base needed to support a successful educational system.

According to sociologists, the current environment prevailing in educational institutions is a reward scarce setting for professional work and often seem to work against the teacher's best efforts to grow professionally and improve student learning (Peterson 1995). Much of a teacher's work is carried out in self-

\footnotetext{
* The author is Manager of the MSc / MBA programmes at the Lahore School of Economics.
} 
contained classrooms that isolate them from the support of their colleagues. Because of this organisational structure, teachers are difficult to supervise, do not receive regular feedback from others and often find it hard to collaborate.

Perhaps as a result of these circumstances, research also shows that many good teachers leave teaching in the first three years (Frase 1992). Clearly the education leaders need to find ways to keep teachers in the profession and keep them motivated and satisfied. A motivated teacher, as described here, is one who not only feels satisfied with his or her job, but is also empowered to strive for excellence and growth in instructional practice.

This research looks at teacher satisfaction and has attempted to investigate and understand factors that contribute to teacher satisfaction (or dissatisfaction). Specifically this study examined the relationship between job satisfaction and four variables: college characteristics, teacher background characteristics, intrinsic factors (teaching itself) and extrinsic factors (the teaching environment) related to satisfaction. Table 1 provides the list of variables under each category:

\section{Table 1: List of Variables}

\begin{tabular}{|c|c|c|c|}
\hline $\begin{array}{l}\text { Teacher } \\
\text { Background } \\
\text { Variables }\end{array}$ & $\begin{array}{l}\text { College } \\
\text { Characteristic } \\
\text { Variables }\end{array}$ & Intrinsic Variables & $\begin{array}{l}\text { Extrinsic } \\
\text { Variables }\end{array}$ \\
\hline Gender & College Sector & Autonomy & Pay \\
\hline Age & College Size & Promotion Prospects & Fringe Benefits \\
\hline $\begin{array}{l}\text { Years of teaching } \\
\text { experience }\end{array}$ & Class Size & Nature of work & $\begin{array}{l}\text { Relationship } \\
\text { with colleagues }\end{array}$ \\
\hline $\begin{array}{l}\text { Years of } \\
\text { education }\end{array}$ & $\begin{array}{l}\text { Location of } \\
\text { the college } \\
\text { with respect } \\
\text { to teachers } \\
\text { residence }\end{array}$ & $\begin{array}{l}\text { Role in college } \\
\text { decision making }\end{array}$ & $\begin{array}{l}\text { Relationship } \\
\text { with immediate } \\
\text { supervisor }\end{array}$ \\
\hline $\begin{array}{l}\text { Teaching field of } \\
\text { the teachers }\end{array}$ & & $\begin{array}{l}\text { Opportunities for } \\
\text { professional } \\
\text { development }\end{array}$ & Job Security \\
\hline Job rank & & $\begin{array}{l}\text { Recognition of } \\
\text { achievement }\end{array}$ & $\begin{array}{l}\text { Administrative } \\
\text { Support }\end{array}$ \\
\hline Job tenure & & $\begin{array}{l}\text { Respect accorded by } \\
\text { the society to the } \\
\text { teaching profession }\end{array}$ & $\begin{array}{l}\text { Student quality } \\
\text { \& behaviour }\end{array}$ \\
\hline
\end{tabular}


Another purpose of this study was to find out if there existed differences in the job satisfaction of public and private sector college teachers teaching in Lahore.

By knowing the factors which affect teacher's satisfaction, it is hoped that the authorities concerned would be able to take appropriate steps to retain and attract high quality individuals to the teaching profession and make academic jobs more satisfying.

\section{What is Job Satisfaction?}

Job satisfaction is an important issue and has received much attention in management. For many years, job satisfaction has been studied as both an independent and a dependent variable in organisational behaviour and industrial psychology (Fisher, 2000). Cranny, Smith, and Stone (1992) estimated that more than 5000 articles and dissertations examining job satisfaction have been published.

Job satisfaction is often described as an affective reaction to a job. In the early years, job satisfaction was referred to as overall feelings about the job (Herzberg, Mausner, \& Snyderman, 1959). Those feelings related to both the job and other people (Lee \& Mitchell, 1994). According to Locke (1976), job satisfaction is "the pleasurable emotional state resulting from the appraisal of one's job as achieving or facilitating the achievement of one's job valued". Schultz and Schultz (1990) defined job satisfaction as "a set of attitudes that employees have about their jobs...Job satisfaction (may be described) as the psychological disposition of people toward their jobs- how they feel about the work - and this involves a collection of numerous attitudes or feelings."

Job satisfaction is an attitude. The attitude might affect employee productivity, absenteeism and turnover. Job satisfaction may also have an impact on the behaviour of employees, the atmosphere of the workplace, or even the feelings of consumers. Thus the managers should deal with this issue seriously.

\section{Methodology \& Findings}

\section{Target Population and Sample Size}

The target population comprised teachers in the private and public sector colleges / universities operating in the city of Lahore. For the purpose of this study a sample of 502 teachers was selected. Out of this, 201 
teachers were from the private sector and 301 belonged to the public sector.

\section{Instrumentation}

The instrument for this study (i.e. the questionnaire) was developed by the researcher through the identification of teacher background characteristics, college characteristics, and intrinsic and extrinsic variables related to job satisfaction. All these characteristics and variables were extracted through the review of related literature.

The questionnaire was divided into three sections. The first section dealt with the background characteristics of the teachers. The respondents were required to provide information about their gender, age, years of teaching experience, years of education, main teaching field, job rank and job tenure.

The second section solicited information regarding the respondent's college characteristics. Specifically this section asked questions about the teachers, college sector, college size, class size and location of the college.

The third section of the questionnaire consisted of 48 statements, which enabled the researcher to gather information about the intrinsic and extrinsic variables related to job satisfaction. Most of these statements were taken from the Job Satisfaction Survey (JSS; Spector, 1997).

All the questions included in section 3 were in a format in which the respondent was asked to indicate on a six-point scale the extent to which they disagree or agree with a particular statement. The scale was presented and scored numerically. Responses ranged from 1, indicating strong disagreement with the statement, to 6 , indicating strong agreement with the statement.

\section{Data Collection Procedure \& Response Rate}

The required number of questionnaires along with an enclosed letter was distributed to the teachers teaching in the selected private and public sector colleges of Lahore through the relevant authorities of the respective colleges. For this study a total of 45 colleges were chosen. Out of these 26 were in the public sector and 19 were in the private sector. The total number of teachers to be surveyed was 502. This included 301 public sector college teachers and 201 private sector college teachers. The relevant people in each institution were given reminder calls approximately one week after the initial 
handing over of the questionnaires. It took about eight weeks to collect the data.

The survey method described above yielded 183 responses $(91.04 \%$ response rate) from the private sector colleges and 268 responses $(89.04 \%$ response rate) from public sector college teachers. Overall an $89.8 \%$ response rate or 451 questionnaires out of a total of 502 were received by the researcher.

\section{Levels of Job Satisfaction Among Academics}

Table 2 - Mean Levels of Facets of Job Satisfaction by Sector

\begin{tabular}{|c|c|c|c|c|c|c|}
\hline Variable & $\begin{array}{l}\text { Private } \\
\text { Sector } \\
\text { (Mean) }\end{array}$ & $\begin{array}{l}\text { Standard } \\
\text { Devi- } \\
\text { ation }\end{array}$ & $\begin{array}{l}\text { Public } \\
\text { Sector } \\
\text { (Mean) }\end{array}$ & $\begin{array}{l}\text { Standard } \\
\text { Devi- } \\
\text { ation }\end{array}$ & $\begin{array}{l}\text { All } \\
\text { (Mean) }\end{array}$ & $\begin{array}{l}\text { Standard } \\
\text { Devi- } \\
\text { ation }\end{array}$ \\
\hline Nature of work & 5.16 & 0.81 & 5.04 & 0.93 & 5.09 & 0.88 \\
\hline $\begin{array}{l}\text { Administration } \\
\text { Support }\end{array}$ & 4.12 & 1.01 & 3.63 & 0.99 & 3.83 & 1.02 \\
\hline $\begin{array}{l}\text { Relation with } \\
\text { colleagues }\end{array}$ & 4.58 & 0.86 & 4.34 & 0.96 & 4.44 & 0.93 \\
\hline $\begin{array}{l}\text { Relation with } \\
\text { supervisor }\end{array}$ & 4.82 & 1.09 & 4.66 & 1.17 & 4.72 & 1.14 \\
\hline $\begin{array}{l}\text { Promotion } \\
\text { Prospects }\end{array}$ & 3.67 & 1.32 & 3.1 & 1.26 & 3.33 & 1.31 \\
\hline Job Security & 3.66 & 1.89 & 4.70 & 1.55 & 4.28 & 1.77 \\
\hline Autonomy & 4.81 & 0.98 & 4.53 & 0.94 & 4.64 & 0.97 \\
\hline $\begin{array}{l}\text { Role in decision } \\
\text { making }\end{array}$ & 3.88 & 1.08 & 3.56 & 0.94 & 3.69 & 1.01 \\
\hline $\begin{array}{l}\text { Opportunities } \\
\text { for Professional } \\
\text { Development }\end{array}$ & 4.61 & 0.96 & 4.34 & 0.97 & 4.45 & 0.97 \\
\hline $\begin{array}{l}\text { Student Quality } \\
\text { \& Behaviour }\end{array}$ & 3.42 & 1.18 & 3.51 & 1.05 & 3.47 & 1.11 \\
\hline $\begin{array}{l}\text { Recognition of } \\
\text { achievement }\end{array}$ & 3.85 & 1.1 & 3.46 & 0.91 & 3.62 & 1.01 \\
\hline Pay & 3.39 & 1.40 & 3.23 & 1.12 & 3.29 & 1.24 \\
\hline Benefits & 3.52 & 1.17 & 3.07 & 0.97 & 3.26 & 1.08 \\
\hline $\begin{array}{l}\text { Perceived } \\
\text { Respect }\end{array}$ & 3.6 & 1.82 & 3.33 & 1.82 & 3.46 & 1.86 \\
\hline $\begin{array}{l}\text { Overall Job } \\
\text { Satisfaction }\end{array}$ & 4.11 & 0.75 & 3.86 & 0.59 & 3.96 & 0.67 \\
\hline
\end{tabular}


Table 2 presents the mean reported levels of job satisfaction by private sector academics, by public sector academics and then across the entire sample. Considering the whole sample first, the results show that the teachers were most satisfied with the nature of work $(M=5.09)$, relationship with immediate supervisor $(M=4.72)$ and autonomy $(M=4.64)$. Academics were least satisfied with fringe benefits $(M=3.26)$, pay $(M=3.29)$ and promotion prospects $(M=3.33)$. Overall the academics seem to be only moderately satisfied with their careers $(M=3.96)$.

Perhaps more interesting are the results by sector, presented in the first four columns of Table 2. The results show that except for job security and student quality and behaviour, the job satisfaction of private sector teachers was higher on every other facet.

Overall the private sector teachers seemed much more satisfied than the teachers teaching in public colleges. The mean overall satisfaction for the private college teachers was 4.11 as opposed to 3.86 for the public sector academics.

Table 3 - Percentage of Highly Satisfied Teachers Public \& Private Teachers

\begin{tabular}{llll}
\hline Facets of Job Satisfaction & All & Private & Public \\
\hline Nature of work & 66 & 70.5 & 63 \\
Administrative Support & 15.7 & 23.5 & 10.1 \\
Relationship with colleagues & 33 & 38 & 29 \\
Relationship with immediate supervisor & 50.55 & 53.55 & 48 \\
Promotion Prospects & 12.6 & 18 & 8.6 \\
Job Security & 59.6 & 44 & 70 \\
Autonomy & 41.9 & 51.4 & 35.1 \\
Role in decision making & 10 & 15.3 & 6 \\
Opportunities for professional development & 41.7 & 48.6 & 36.6 \\
Student Quality \& Behaviour & 11.8 & 11.5 & 11.6 \\
Recognition of achievement & 9.5 & 15.8 & 5 \\
Pay & 9.5 & 21.3 & 5 \\
Benefits & 7.1 & 15.8 & 2.2 \\
Perceived Respect & 36 & 38.8 & 34 \\
Overall Satisfaction & 7.3 & 13.6 & 3 \\
\hline
\end{tabular}


Table 4:- Percentage of Highly Dissatisfied Teachers Public \& Private Teachers

\begin{tabular}{llll}
\hline Facets of Job Satisfaction & All & Private & Public \\
\hline Nature of work & 2.4 & 2.2 & 2.6 \\
Administrative Support & 18.8 & 13.1 & 22.8 \\
Relationship with colleagues & 5.3 & 2.7 & 7.1 \\
Relationship with immediate supervisor & 8 & 7.1 & 8.6 \\
Promotion Prospects & 35.7 & 26.2 & 42 \\
Job Security & 20.8 & 33.33 & 12.3 \\
Autonomy & 4 & 4.4 & 3.7 \\
Role in decision making & 20.6 & 17.5 & 22.8 \\
Opportunities for professional development & 4.4 & 3.3 & 5.2 \\
Student Quality \& Behaviour & 30.6 & 33.9 & 28.4 \\
Recognition of achievement & 22.6 & 18.6 & 25.7 \\
Pay & 37.7 & 37.7 & 37.7 \\
Benefits & 35 & 27.9 & 40 \\
Perceived Respect & 38.5 & 35 & 41 \\
Overall Satisfaction & 7.1 & 6.6 & 7.5 \\
\hline
\end{tabular}

Tables 3 and 4 represent the percentage of academics highly satisfied and highly dissatisfied respectively with the intrinsic and extrinsic aspects of their job as well as overall job satisfaction, where highly satisfied is defined as reports of mean satisfaction between 5 and 6 and highly dissatisfied implies reports of mean satisfaction between 1 and 2.99. Considering the reports by the whole sample first, results showed that nearly three quarters of the academics were highly satisfied with the nature of work they do and over half were highly satisfied with their relationship with the immediate supervisor and job security. In contrast only $7.1 \%$ of the academics were highly satisfied with benefits, $9.5 \%$ with pay and recognition of achievement, $10 \%$ with role in decision-making and $12.6 \%$ with promotion. Over one third of the academics were highly dissatisfied with promotion, pay, benefits and respect accorded by the society (Table 4).

Analysing these statistics by sector it was found that there were significant differences in reports for private and public sector teachers in almost all aspects of job satisfaction. The most glaring differences were found in administrative support, promotion prospects, job security, role in decision-making, recognition of achievement, pay and benefits. In all these 
aspects of job satisfaction except job security, the proportion of highly satisfied teachers was far greater for the private sector as compared to the public sector (Table 3). Table 4 also suggests that a larger proportion of public sector teachers as compared to private sector academics were highly dissatisfied with the benefits, respect accorded by the society to the teaching profession and promotion prospects whereas the percentage of highly dissatisfied teachers with respect to job security was larger for private academics. Table 3 also revealed that the percentage of highly satisfied teachers in the private sector $(13.6 \%)$ is more than four times the percentage of highly satisfied teachers in the public sector (3\%). Clearly the private sector academics seemed to be much more satisfied with the teaching profession than their public sector counterparts.

\section{Determinants of Job Satisfaction Among Private Sector Teachers}

To gain an idea of how the teacher background and college characteristic variables were correlated with overall job satisfaction for the private and public sector academics, use was made of the OLS multiple regression analysis and the following model was estimated:

$Y=\beta_{0}+\beta_{1} X_{1}+\beta_{2} X_{2}+\beta_{3} X_{3}+\beta_{4} X_{4}+\beta_{5} X_{5}+\beta_{6} X_{6}+\beta_{7} D_{1}+\beta_{8} D_{2}+\beta_{9} D_{3}+$

$\beta_{10} D_{4}+\beta_{11} D_{5}+\beta_{12} D_{6}+\beta_{13} D_{7}+\beta_{14} D_{8}$

Where:

$\mathrm{Y}=$ Standardised score of overall job satisfaction

$\mathrm{X}_{1}=$ Age

$\mathrm{X}_{2}=$ Years of teaching experience

$\mathrm{X}_{3}=$ Years of education

$\mathrm{X}_{4}=$ College Size

$\mathrm{X}_{5}=$ Class Size

$\mathrm{X}_{6}=$ Location

$\mathrm{D}_{1}=1$ if male

$=0$ otherwise

$D_{2}=1$ if the teacher is a permanent faculty member 
$=0$ otherwise

$D_{3}=1$ if the teacher teaches within the faculty of social sciences

$=0$ otherwise

$D_{4}=1$ if the teacher teaches within the faculty of science \& engineering

$=0$ otherwise

$D_{5}=1$ if the teacher teaches within the faculty of business management

$=0$ otherwise

$\mathrm{D}_{6}=1$ if the teacher is an Assistant Professor

$=0$ otherwise

$\mathrm{D}_{7}=1$ if the teacher is an Associate Professor

$=0$ otherwise

$\mathrm{D}_{8}=1$ if the teacher is a Full Professor

$=0$ otherwise

The dependent variable, that is the overall job satisfaction was rescaled to produce $\mathrm{Z}$-scores through the following transformation:

$$
Z=(X-\mu) \text { S.D. }
$$

Where $\mathrm{X}$ is the overall job satisfaction, $\mu$ is the mean overall job satisfaction and S.D. is the standard deviation.

This was done because the OLS regression using variables with ordered scales such as the measure of overall job satisfaction in this study may produce biased results (Sloane and Williams 1996b). Because of this transformation the slope coefficient of 0.7 on age for example implied that every one-year change in age leads to a 0.7 standard deviation change in the overall job satisfaction.

Tables 5 and 6 show the multiple regression analysis and analysis of variance summary when the overall job satisfaction of private sector 
The Lahore Journal of Economics, Vol.8, No.1

teachers is regressed against the teacher background and college characteristic variables.

Table 5: The Multiple Regression Analysis when Job Satisfaction of Private Sector Teachers is Regressed against Teacher Background Variables and College Characteristics

\begin{tabular}{lllll}
\hline Predictor & Coefficient & Standard Error & T-statistic & P-value \\
\hline Constant & -0.5698 & 0.7869 & -0.72 & 0.470 \\
Age & 0.00175 & 0.01192 & 0.15 & 0.884 \\
Years of & 0.01529 & 0.01880 & 0.81 & 0.417 \\
experience & & & & \\
Years of & 0.03134 & 0.03556 & 0.88 & 0.379 \\
education & & & & \\
College Size & 0.0002409 & 0.0003108 & 0.78 & 0.439 \\
Class Size & -0.012984 & 0.007109 & -1.83 & $0.070^{*}$ \\
Location & -0.03800 & 0.01326 & -2.87 & $0.005^{* * *}$ \\
$\begin{array}{l}\text { Gender } \\
\text { Job Tenure }\end{array}$ & 0.0850 & 0.1869 & 0.45 & 0.650 \\
$\begin{array}{l}\text { Social } \\
\text { Science }\end{array}$ & 0.5435 & 0.2499 & -0.01 & 0.989 \\
Science \& & 0.5332 & 0.2548 & 2.17 & $0.031^{* *}$ \\
$\begin{array}{l}\text { Engineering } \\
\text { Business }\end{array}$ & 0.5073 & 0.2728 & 2.09 & $0.038^{* *}$ \\
$\begin{array}{l}\text { Management } \\
\text { Assistant }\end{array}$ & -0.1097 & 0.2108 & 1.86 & $0.065^{*}$ \\
$\begin{array}{l}\text { Professor } \\
\text { Associate }\end{array}$ & 0.2823 & 0.2407 & -0.52 & 0.603 \\
$\begin{array}{l}\text { Professor } \\
\text { Full }\end{array}$ & 0.0423 & 0.2737 & 1.17 & 0.243 \\
Professor & & & 0.15 & 0.877 \\
\hline Statisticaly & & & & \\
\hline
\end{tabular}

*Statistically significant at the 0.10 level; **Statistically significant at the 0.05 leve1; ***Statistically significant at the 0.01 level

$\mathrm{R}^{2}=18.9 \%$ Adjusted $\mathrm{R}^{2}=12.1 \%$ 
Table 6 - The Multiple Regression Analysis when Job Satisfaction of Private Sector Teachers is Regressed Against Teacher Background Variables and College Characteristics

\begin{tabular}{llllll}
\hline Source & DF & SS & MS & F- statistic & P-value \\
\hline Regression & 14 & 32.1897 & 2.2993 & 2.77 & 0.001 \\
Error & 168 & 137.7670 & 0.8299 & & \\
Total & 182 & 169.9566 & & & \\
\hline
\end{tabular}

From Table 5 it can be seen that all the teacher background variables except the dummy variables pertaining to teaching field are statistically insignificant at the $95 \%$ confidence interval. For all these variables the P-value as indicated by the last column is greater than 0.05 . Thus age, years of teaching experience and years of education were found to be unrelated to the job satisfaction of private sector teachers. Similarly the dummy variables for job status, gender, and job tenure were found to be statistically insignificant. This implied that in the private sector there was no difference in the satisfaction of teachers of different ranks, male and female teachers and permanent and visiting faculty. However all the dummy variables for the main teaching field, that is social science, science and engineering and business management were found to be statistically significant. The positive signs of the coefficients of these dummies indicated that the job satisfaction of teachers teaching in the faculties of social sciences, science and engineering and business management was greater than the teachers teaching in the faculty of arts. Thus the teaching field of the teachers proved to be an important determinant of the overall satisfaction of private sector teachers.

Table 5 also reveals that out of the three college characteristic variables, class size is statistically significant at the $90 \%$ confidence interval whereas the P-value for location is less than 0.01 , which implies that this variable is statistically significant at the $99 \%$ confidence interval. However college size is statistically insignificant as indicated by its high P-value. The coefficients of both the significant variables have negative signs. The negative sign for class size implies that the job satisfaction of private sector teachers increases with a decrease in class size. On the other hand the negative coefficient of location means that people who live far from their workplace are less satisfied than those who live nearer their colleges.

Table 6 presents the analysis of variance summary. Since the P-value (0.001) in the analysis of variance Table is less than 0.01 , there is a 
statistically significant relationship between the job satisfaction of private sector teachers and the teacher background and college characteristic variables at the $99 \%$ confidence interval. The $\mathrm{R}^{2}$ statistic indicates that these variables together explained $18.9 \%$ of the variability in job satisfaction of teachers teaching in the private sector colleges.

In order to determine the relationship between the overall job satisfaction of private sector teachers and the extrinsic and intrinsic variables, the researcher used the Pearson Correlation Coefficients. Appendix 1 gives the Pearson correlation matrix for the private sector teachers.

The independent variables are the extrinsic and intrinsic factors. The extrinsic factors are: administrative support, pay, relationship with colleagues, relationship with immediate supervisor, student quality and behaviour, benefits and job security. The intrinsic factors are: nature of work, promotion prospects, recognition of achievement, autonomy, role in decision making, opportunities for professional development and the respect accorded to the teaching profession by society. The dependent variable is job satisfaction. It should be carefully noted that this analysis cannot address issues of causality. It only looks at the extent to which the two variables tend to move together and the degree of intensity in the relationship of two variables.

From the Pearson correlation matrix given in Appendix 1, it can be seen that the most closely related extrinsic factors to the overall job satisfaction of private teachers are pay $(\mathrm{r}=0.826)$, fringe benefits $(\mathrm{r}=$ $0.748)$, and relationship with colleagues $(\mathrm{r}=0.696)$. The least closely related extrinsic factor is job security $(r=0.539)$. All the correlation coefficients have positive signs, which implies that there is a positive correlation between job satisfaction and each of the extrinsic variables. Thus an increase in pay for example will lead to a corresponding increase in job satisfaction. The correlation coefficients between job satisfaction and each of the extrinsic variables are statistically significant at the $99 \%$ confidence interval implying that there exists a significant relationship between the overall job satisfaction of private sector teachers and the extrinsic variables.

Promotion prospects $(\mathrm{r}=0.801)$ and, recognition of achievement $(\mathrm{r}=$ 0.752) are the two most closely related intrinsic factors with overall job satisfaction. The least related intrinsic factor is the respect accorded by society to the teaching profession $(r=0.301)$. Like the extrinsic variables, the correlation coefficients between job satisfaction and each of the intrinsic variables are significant at the $99 \%$ confidence interval. Thus from this analysis it can be inferred that both the intrinsic and extrinsic variables are closely 
related to the overall job satisfaction of teachers. Thus the three most important determinants of job satisfaction for the private sector teachers are pay $(\mathrm{r}=0.826)$, promotion $(\mathrm{r}=0.801)$ and recognition of accomplishment $(\mathrm{r}=$ $0.752)$.

\section{Determinants Of Job Satisfaction Among Public Sector Teachers}

Tables 6 and 7 present the results of the multiple regression analysis when overall job satisfaction of public sector teachers was regressed against teacher background and college characteristic variables.

Table 6 - Multiple Regression Analysis when overall Job Satisfaction of Public Sector Teachers was Regressed Against Teacher Background and College Characteristic Variables

\begin{tabular}{lllll}
\hline Predictor & Coefficient & Standard Error & T-statistic & P-value \\
\hline Constant & 0.4472 & 0.8112 & 0.55 & 0.582 \\
Age & -0.02029 & 0.01283 & -1.58 & 0.115 \\
Years of experience & 0.02918 & 0.01708 & 1.71 & $0.089^{*}$ \\
Years of education & -0.03041 & 0.02968 & -1.02 & 0.307 \\
College Size & 0.0005344 & 0.0006125 & 0.87 & 0.384 \\
Class Size & -0.006945 & 0.006063 & -1.15 & 0.253 \\
Location & -0.02859 & 0.101099 & -2.60 & $0.010^{* *}$ \\
Gender & -0.0550 & 0.1340 & -0.41 & 0.682 \\
Job Tenure & 0.5643 & 0.2353 & 2.40 & $0.017^{* *}$ \\
Social Science & 0.0737 & 0.1588 & 0.46 & 0.643 \\
Science \& & 0.1717 & 0.1627 & 1.06 & 0.292 \\
Engineering & & & & \\
Business Management & 0.6341 & 0.3819 & 1.66 & $0.098^{*}$ \\
Assistant Professor & 0.0761 & 0.1613 & 0.47 & 0.638 \\
Associate Professor & 0.1464 & 0.2569 & 0.57 & 0.569 \\
Full Professor & -0.3432 & 0.4896 & -0.70 & 0.484 \\
\hline
\end{tabular}

*Statistically significant at the 0.10 level; **Statistically significant at the 0.05 leve1; $* * *$ Statistically significant at the 0.01 level

$\mathrm{R}^{2}=9.1 \%$ Adjusted $\mathrm{R}^{2}=4.1 \%$ 
104 The Lahore Journal of Economics, Vol.8, No.1

Table 7- Analysis of Variance when overall Job Satisfaction of Public Sector Teachers is Regressed against the Teacher Background Variables and the College Characteristics

\begin{tabular}{llllll}
\hline Source & DF & SS & MS & F-statistic & P-value \\
\hline Regression & 14 & 24.3461 & 1.7390 & 1.81 & 0.037 \\
Error & 253 & 242.6539 & 0.9591 & & \\
Tota1 & 267 & 267.0000 & & & \\
\hline
\end{tabular}

From Table 6 it can be seen that of the teacher background variables, only the years of teaching experience, tenure and the dummy for Business Management are statistically significant. Tenure is significant at the $95 \%$ confidence interval whereas the years of teaching experience and the dummy for business management are significant at the $90 \%$ confidence interval. The sign of the coefficient of tenure is positive which indicates that the permanent faculty members are more satisfied then the visiting teachers. The positive sign on the coefficient of years of experience indicates that the more experienced teachers are more satisfied with their jobs. The positive sign on the coefficient of the business management dummy implies that in the public sector the teachers teaching in the faculty of business management are more satisfied than their colleagues in the faculty of arts.

From Table 6 it can also be seen that the P-value for both the college size and the class size variables is greater than 0.05 implying that both these variables are statistically insignificant. Location however is statistically significant at the $95 \%$ confidence interval. The negative sign on its coefficient implies that teachers living nearer their workplace are more satisfied with their jobs. The $\mathrm{R}^{2}$ statistic indicates that the college characteristic and teacher background variables as a group explain $9.1 \%$ of the variation in overall job satisfaction of the public sector teachers.

The P-value (0.037) in Table 7 is less than 0.05 , which means that college characteristic and teacher background variables as a group significantly explain variance in the overall job satisfaction of public sector teachers.

The Pearson correlation matrix was estimated to determine the relationship between the overall job satisfaction of public sector teachers and the intrinsic and extrinsic variables related to teacher satisfaction. This matrix which is given in Appendix 2, reveals that the most closely related extrinsic factors with overall job satisfaction, are pay $(\mathrm{r}=0.636)$ and administrative support $(\mathrm{r}=0.631)$. The least related factor is job security $(\mathrm{r}$ 
$=0.4)$. The correlation coefficients between the overall job satisfaction and each of the extrinsic variables are significant at the $99 \%$ confidence interval.

As far as the intrinsic variables are concerned, recognition of achievement $(\mathrm{r}=0.632)$ and opportunities for professional development (0.604) are most closely related with the overall job satisfaction of teachers. The respect accorded to the teaching profession by society is least related with the overall job satisfaction of teachers $(r=0.407)$. The correlation coefficients between job satisfaction and each of the intrinsic factors are significant at the $99 \%$ level of significance. From this analysis it can be deduced that pay, recognition of achievement and administrative support are the three most closely associated variables with overall job satisfaction of public college teachers. 
Differences in the Job Satisfaction of Private and Public Sector Teachers Table 8- Summary of Survey Responses and Tests of Difference in Means Using Z-Test (Public and Private Sector Teachers)

\begin{tabular}{|c|c|c|c|c|c|c|}
\hline Sub- Scale & Sector & $\begin{array}{l}\text { Number } \\
\text { of respon- } \\
\text { dents }\end{array}$ & $\begin{array}{l}\text { Mean } \\
\text { Response }\end{array}$ & $\begin{array}{l}\text { Standard } \\
\text { Deviation }\end{array}$ & Z-Stat & $\begin{array}{l}\text { Significance } \\
\text { (P-value) }\end{array}$ \\
\hline Nature of & Public & 268 & 5.04 & 0.93 & 1.45 & 0.15 \\
\hline Work & $\begin{array}{l}\text { Private } \\
\text { Total }\end{array}$ & $\begin{array}{l}183 \\
451\end{array}$ & 5.16 & 0.81 & & \\
\hline Admin. & Public & 268 & 3.63 & 0.99 & 5.10 & $0.0000^{*}$ \\
\hline Support & $\begin{array}{l}\text { Private } \\
\text { Total }\end{array}$ & $\begin{array}{l}183 \\
451\end{array}$ & 4.12 & 1.01 & & \\
\hline $\begin{array}{l}\text { Relation with } \\
\text { colleagues }\end{array}$ & $\begin{array}{l}\text { Public } \\
\text { Private } \\
\text { Total }\end{array}$ & $\begin{array}{l}268 \\
183 \\
451\end{array}$ & $\begin{array}{l}4.34 \\
4.58\end{array}$ & $\begin{array}{l}0.96 \\
0.86\end{array}$ & 2.77 & $0.007^{*}$ \\
\hline $\begin{array}{l}\text { Relation with } \\
\text { Supervisor }\end{array}$ & $\begin{array}{l}\text { Public } \\
\text { Private } \\
\text { Total }\end{array}$ & $\begin{array}{l}268 \\
183 \\
451\end{array}$ & $\begin{array}{l}4.66 \\
4.82\end{array}$ & $\begin{array}{l}1.17 \\
1.09\end{array}$ & 1.49 & 0.14 \\
\hline $\begin{array}{l}\text { Promotion } \\
\text { Prospects }\end{array}$ & $\begin{array}{l}\text { Public } \\
\text { Private } \\
\text { Total }\end{array}$ & $\begin{array}{l}268 \\
183 \\
451\end{array}$ & $\begin{array}{l}3.1 \\
3.67\end{array}$ & $\begin{array}{l}1.26 \\
1.32\end{array}$ & 4.59 & $0.0000^{*}$ \\
\hline Job Security & $\begin{array}{l}\text { Public } \\
\text { Private } \\
\text { Total }\end{array}$ & $\begin{array}{l}268 \\
183 \\
451\end{array}$ & $\begin{array}{l}4.70 \\
3.66\end{array}$ & $\begin{array}{l}1.55 \\
1.89\end{array}$ & 6.16 & $0.0000^{*}$ \\
\hline Autonomy & $\begin{array}{l}\text { Public } \\
\text { Private } \\
\text { Total }\end{array}$ & $\begin{array}{l}268 \\
183 \\
451\end{array}$ & $\begin{array}{l}4.53 \\
4.81\end{array}$ & $\begin{array}{l}0.94 \\
0.98\end{array}$ & 3.03 & $0.002^{*}$ \\
\hline $\begin{array}{l}\text { Role in } \\
\text { Decision } \\
\text { Making }\end{array}$ & $\begin{array}{l}\text { Public } \\
\text { Private } \\
\text { Total }\end{array}$ & $\begin{array}{l}268 \\
183 \\
451\end{array}$ & $\begin{array}{l}3.56 \\
3.88\end{array}$ & $\begin{array}{l}0.94 \\
1.08\end{array}$ & 3.25 & $0.0012 *$ \\
\hline $\begin{array}{l}\text { Opportunities } \\
\text { for PD }\end{array}$ & $\begin{array}{l}\text { Public } \\
\text { Private } \\
\text { Total }\end{array}$ & $\begin{array}{l}268 \\
183 \\
451\end{array}$ & $\begin{array}{l}4.34 \\
4.61\end{array}$ & $\begin{array}{l}0.97 \\
0.96\end{array}$ & 2.92 & $0.004^{*}$ \\
\hline $\begin{array}{l}\text { Student } \\
\text { Quality \& } \\
\text { Behaviour }\end{array}$ & $\begin{array}{l}\text { Public } \\
\text { Private } \\
\text { Total }\end{array}$ & $\begin{array}{l}268 \\
183 \\
451\end{array}$ & $\begin{array}{l}3.51 \\
3.42\end{array}$ & $\begin{array}{l}1.05 \\
1.18\end{array}$ & 0.83 & 0.41 \\
\hline $\begin{array}{l}\text { Recognition of } \\
\text { achieve-ment }\end{array}$ & $\begin{array}{l}\text { Public } \\
\text { Private } \\
\text { Total }\end{array}$ & $\begin{array}{l}268 \\
183 \\
451\end{array}$ & $\begin{array}{l}3.46 \\
3.85\end{array}$ & $\begin{array}{l}0.91 \\
1.1\end{array}$ & 3.96 & $0.0000^{*}$ \\
\hline Pay & $\begin{array}{l}\text { Public } \\
\text { Private } \\
\text { Total }\end{array}$ & $\begin{array}{l}268 \\
183 \\
451\end{array}$ & $\begin{array}{l}3.23 \\
3.39\end{array}$ & $\begin{array}{l}1.12 \\
1.40\end{array}$ & 1.29 & 0.2 \\
\hline Benefits & $\begin{array}{l}\text { Public } \\
\text { Private } \\
\text { Total }\end{array}$ & $\begin{array}{l}268 \\
183 \\
451\end{array}$ & $\begin{array}{l}3.07 \\
3.52\end{array}$ & $\begin{array}{l}0.97 \\
1.17\end{array}$ & 4.29 & $0.0000^{*}$ \\
\hline Perceived & Public & 268 & & & & \\
\hline Respect & $\begin{array}{l}\text { Private } \\
\text { Total }\end{array}$ & $\begin{array}{l}183 \\
451\end{array}$ & $\begin{array}{l}3.33 \\
3.6\end{array}$ & $\begin{array}{l}1.88 \\
1.82\end{array}$ & 1.53 & 0.13 \\
\hline $\begin{array}{l}\text { Overall Job } \\
\text { Satisfaction }\end{array}$ & $\begin{array}{l}\text { Public } \\
\text { Private } \\
\text { Total }\end{array}$ & $\begin{array}{l}268 \\
183 \\
451\end{array}$ & $\begin{array}{l}3.86 \\
4.11\end{array}$ & $\begin{array}{l}0.59 \\
0.75\end{array}$ & 3.78 & $0.0002 *$ \\
\hline
\end{tabular}

*Indicates that a significant difference exists at the $5 \%$ level of significance. 
Table 8 presents the mean response for each variable for both the private and public sector. The columns 6 and 7 of Table 8 show the Zstatistics and significance levels for a test of the difference in the mean responses between the two sectors.

From Table 8 it can be seen that there are significant differences in mean responses of private and public sector college teachers on almost every facet of job satisfaction. However there are several similarities worth noting. Perhaps the most important is that the two sectors have nearly identical levels of satisfaction with respect to the nature of the work they do. There were four other aspects of their work in which the two groups did not have significantly different responses: the relationship with their immediate supervisors, their perception of student quality and behaviour, their attitude towards their pay and their perception of the respect accorded to them by society. As far as pay was concerned, it was expected that the private sector teachers would exhibit a higher level of satisfaction than their public sector counterparts. However teachers of both the sectors had low levels of satisfaction with respect to pay and their feelings about this aspect did not differ significantly. On all other aspects there were significant differences in the mean responses of both the sectors. The most glaring differences between the two sectors were found with respect to job security, promotion prospects and fringe benefits. Except for job security, in all other aspects the satisfaction of private college teachers was significantly higher. In order to see whether overall the private sector teachers had a higher level of satisfaction, the following hypothesis was formulated and tested by using the Z-test for difference of means:

$$
\begin{aligned}
& \mathrm{H}_{0}: \mu_{\text {private }}-\mu_{\text {public }}=0 \\
& \mathrm{H}_{1}: \mu_{\text {private }}-\mu_{\text {public }}>0
\end{aligned}
$$

The Z-statistic for this analysis was found to be 3.78 and the P-value was 0.0000 . Since the P-value was less than 0.05 , the null hypothesis that the public and private sector teachers had similar satisfaction, was rejected. Consequently it was concluded that the private sector teachers had a higher level of overall satisfaction with the teaching profession than their public sector counterparts.

To sum up, the overall findings of the above analysis indicated that private sector teachers were significantly more satisfied with their careers than their public sector colleagues. However, the teachers from the two sectors were equally satisfied with the actual work that they performed. That is the differences in job satisfaction of the private and public sector teachers were not 
differences in satisfaction with job content, but rather differences in satisfaction with the environment in which the teacher's work was performed.

\section{Discussion}

From the above analysis some interesting facts came to light. Firstly, of the teacher background and college characteristic variables, the location of teacher's college with respect to his / her residence was found to be most closely related with teacher satisfaction. Location was closely related with the overall job satisfaction of both public and private sector teachers. The negative sign on the coefficient of location indicated that the teachers who lived nearer their workplace were more satisfied than teachers who lived far away. The teachers who have to cover long distances to reach their colleges or universities have to incur a substantial expenditure on petrol, which adds to their expenses. Moreover teachers who are dependent on public transport to get to their colleges have to incur high transportation costs and bear undue inconvenience due to the vagaries of the public transport system. All this leads to dissatisfaction and frustration.

Secondly, class size was significantly related to the satisfaction of private sector teachers. The coefficient of class size had a negative sign implying that job satisfaction of teachers declined with an increase in class size. However, class size was found to be unrelated to the job satisfaction of public sector teachers.

Most of the private sector colleges operate under the semester system. Under the semester system a student's grade comprises mid-term and final examination results, projects, assignments and quizzes. All these activities have to be coordinated by the teacher himself. Thus large class sizes imply more workload, which causes dissatisfaction among teachers. The public colleges on the other hand operate on an annual system. Teachers seldom give quizzes or assignments. The examination papers are set and marked by individuals appointed by the examining university. The workload of a public sector teacher is mostly restricted to giving lectures. Therefore the size of the class is not that relevant for public sector teachers.

Finally, it was found that for the public sector teachers job satisfaction increased as their years of teaching experience increased. However, in the case of private sector academics years of teaching experience was found to be statistically insignificant. With experience the teachers gain a stronger grip over their subjects and they are able to control classroom activities more effectively. Moreover, with experience the chances 
of promotion and pay raises also increase. All this positively contributes to their job satisfaction.

Literature revealed a divergent relationship between the teacher background variables and job satisfaction. For example as far as age is concerned, Abd Main (1993) in his study found out that age did not influence teachers' job satisfaction. However Gibson \& Klien (1970), Jansen \& Martin (1982), Cohen \& Brawer (1982) and Lee \& Wilbur (1985) all found that job satisfaction of teachers increased with age. The findings of this study revealed that age was unrelated to teacher satisfaction in both the private and public sectors.

Studies have revealed a dichotomy in the relationship between job satisfaction and gender. Freisen et al. (1983), Mwange and McCaslin (1994), and Varca et al. (1983) found that male faculty members were more satisfied with their jobs than female faculty. Conversely, Hodson (1989) and Kelly (1989) and Abd Main (1993) found that female employees have higher job satisfaction than males. In this study, gender was found to be unrelated with teacher satisfaction in both the sectors.

As far as years of teaching experience is concerned, Wong (1986) and Bertz and Judge (1994) found that overall job satisfaction increased as the number of years of teaching experience increased. Findings of this study revealed that for the public sector teachers, the years of teaching experience was related to teacher satisfaction. Teachers with more experience were found to be more satisfied with their jobs. In the case of the private sector teachers however, the years of teaching experience was not significantly related with job satisfaction.

The statistical analysis report published by the National Center for Education Statistics, Washington DC (July 1997) and the study conducted by Abd Main in Malaysia (1993) pointed out that the level of education had no relation with teacher satisfaction. This study also found the level of education to be unrelated with the job satisfaction of teachers in both sectors.

Studies have revealed that class size is an important determinant of job satisfaction among teachers. Gretzinger (1992), Graham (1985) and Frase (1992) have found that reduction in class size enhances teacher satisfaction. The results of this study reveal that for private sector teachers, smaller class sizes increased satisfaction. However in the public sector it was found that there was no relationship between teacher satisfaction and class size. 
As far as intrinsic and extrinsic factors were concerned, both were closely related to the job satisfaction of both public and private teachers. For the private sector teachers, pay $(\mathrm{r}=0.826)$, recognition of achievement $(\mathrm{r}=0.752)$ and promotion prospects $(\mathrm{r}=0.801)$ came out as the most important determinants of teacher satisfaction. In the public sector, pay $(\mathrm{r}=$ 0.636) and recognition of achievement $(\mathrm{r}=0.632)$ were the two factors which were most closely related to job satisfaction. Other factors like nature of work, interpersonal relations, administrative support, autonomy, role in decision-making, opportunities for professional development, student quality and behaviour and fringe benefits were also significantly related with the job satisfaction of academics. The overall job satisfaction of teachers was positively correlated with the intrinsic and extrinsic factors. These findings were well supported by the literature.

Gretzinger (1992) identified "seeing students achieve", opportunity to influence young people, feeling of worthwhile accomplishment, higher salaries and reduced teaching load as the main determinants of job satisfaction among Arizona exemplary teachers. Gretzinger also concluded that, overall, intrinsic motivators provide better incentives for educators; however some extrinsic motivators are important as well.

Simmons (1970) identified teacher satisfaction factors and categorised them as content and context. The content factors related to the teaching process itself (e.g., achievement in teaching, the nature of the work itself, and recognition), while context factors related to the job situation (e.g., interpersonal relations, school policy, salary, etc.). Simmons had concluded that those factors that were content-centered (i.e., intrinsic aspects of teaching) contributed most powerfully to satisfaction.

Clarke and Keating (1995) discovered that interaction with students was the most satisfying aspect for teachers, while lack of administrative support was the least satisfying aspect.

Johnson (1967) identified five factors (achievement, recognition, interpersonal relations, work itself, and responsibility) that had statistical significance in affecting teacher satisfaction. He also found four factors (policy and administration, working conditions, status and personal life) that were significant in affecting teacher dissatisfaction.

In a study of job satisfaction that focused on high school business teachers in Ohio, Lacy (1968) identified 27 factors that were significant for a high level of teacher satisfaction. School administration was found to affect teacher job satisfaction. That is, teachers with a high level of job satisfaction 
indicated, "[they] received recognition for a job well done ... administrators had democratic methods of dealing with teachers".

The Minnesota Satisfaction Questionnaire (MSQ) was used by Steinbach (1979) to measure the level of job satisfaction for public secondary industrial arts teachers in Minnesota. The evidence from Steinbach's study indicated that certain job characteristics of industrial arts teachers were significantly associated with their level of satisfaction. The strongest associations were among the following characteristics: steady employment, working conditions, position in the community, feeling of accomplishment, supervisory competence, administrative support, judgmental freedom, organisational practices, authority, and competitive pay.

A recent report on job satisfaction among American teachers identified "more administrative support and leadership, good student behaviour, a positive school atmosphere, and teacher autonomy" as working conditions associated with higher teacher satisfaction (National Center for Education Statistics 1997). Favourable workplace conditions were positively related to the teacher's job satisfaction regardless of whether a teacher was employed by a public or private school, an elementary or secondary school, and regardless of teachers' background characteristics or school demographics (National Center for Education Statistics).

Frase (1992) identified two sets of factors that affect teachers' ability to perform effectively: Work context factors (the teaching environment) and the Work content factors (teaching).

Work context factors were those that met baseline needs. They included working conditions such as class size, disciplinary conditions, and availability of teaching materials; the quality of the principal's supervision; and basic psychological needs such as money, status, and security.

In general, context factors clear the road of the debris that block effective teaching. In adequate supply, these factors prevent dissatisfaction. Even the most intrinsically motivated teacher will become discouraged if the salary does not pay the mortgage.

Work content factors are intrinsic to the work itself. They include opportunities for professional development, recognition, challenging and varied work, increased responsibility, achievement, empowerment and authority. Some researchers argue that teachers who do not feel supported in these states are less motivated to do their best work in the classroom (National Center of Education Statistics, USA, 1997). 
Unfortunately, not much work has been done on the job satisfaction of teachers in Pakistan. Therefore the researcher was unable to quote relevant references from Pakistan.

It can be concluded from the above stated studies that both the intrinsic and extrinsic factors are closely related to teacher satisfaction and the findings of this study are in line with these referred studies.

\section{Recommendations}

On the basis of the findings and results of this study the following recommendations are made:

1. In order to retain and attract high quality teachers, the education managers in the country must come up with policies which not only enhance the intrinsic rewards of teachers but also improve the working conditions and compensation structure. The results of this study have revealed that teachers are most dissatisfied with three aspects: promotion prospects, pay and benefits. The dissatisfaction with these facets seem to be higher in the public sector, where promotion is by number of years of experience, with a pay increment at the end of the year in accordance with a nationally agreed scale. Thus it is recommended that pay and promotion should be tied to performance rather than seniority. The education managers should also think about increasing the rate of increase in salaries. More fringe benefits in the form of free medical, company cars, subsidised meals etc. also have to be provided to the teachers to increase their satisfaction with the profession. The findings of this study pointed out that the teachers in both sectors were dissatisfied with the fringe benefits they were receiving. Unless the teachers are offered better financial rewards the retention of high quality faculty would be extremely difficult. As Frase (1992) has pointed out "Even the most intrinsically motivated teacher will become discouraged if the salary doesn't pay the mortgage".

2. Secondly, it is recommended that there should be greater recognition of accomplishment in terms of rewards. The results of this study have indicated that recognition of achievement is strongly correlated with the job satisfaction of both public and private sector teachers. Teachers in both the sectors frequently complain that there are too few rewards in the teaching profession and that their efforts are not rewarded, as they should be. Rewards in return for good performance are crucial for motivating teachers and enhancing their satisfaction. 
3. Opportunities for skill enhancement and professional development are a must for teachers to improve the quality of their instruction. Findings of this study revealed that the opportunities for training and development were strongly related to teacher satisfaction in both the sectors $(\mathrm{r}=$ 0.553 for the private sector and $r=0.604$ for the public sector). The teachers should be sent for courses, seminars and other relevant workshops to improve their teaching skills. This would not only improve their teaching skills but also increase their job satisfaction. The ultimate beneficiaries would be the students who would benefit from the improved quality of teaching.

4. Finally, it is recommended that the educational institutions should make their admission criteria more stringent so that only the very best students are given admission. This is particularly applicable to the private sector where the admission criteria are relatively lenient. Teachers almost universally treasure student responsiveness and enthusiasm as a vital factor in their own enthusiasm, and conversely list low motivation in students as a major source of dissatisfaction. Thus the college administrators should try to improve the quality of students at their institutions.

\section{Concluding Remarks}

In order to enhance teacher satisfaction, the education policy makers should strive to not only increase the intrinsic rewards (like autonomy and esteem) of teachers, but also try to bring about an improvement in the "work context" factors, like salary, fringe benefits and the overall working conditions. Therefore, efforts to retain outstanding teachers should probably focus on ensuring that they can do their best work without disruption or financial hardship.

Improving the satisfaction of current teachers, however, will require more than improved pay, status, or working conditions. It would require the orchestration of organisational incentives that encourage teachers to think about their work in new ways and commit themselves to new standards and goals. Such purposive and positive incentives would help to co-ordinate teachers' efforts, provide them shared purposes, enhance the conditions of their work, and reaffirm their professional identity. When a teacher remains motivated and satisfied with the teaching profession, the students not only learn the content taught by the teacher, but are also motivated towards learning (Czubaj, 1996). 
114 The Lahore Journal of Economics, Vol.8, No.1

Appendix 1 - Pearson Correlation Matrix (Private Sector Teachers)

\begin{tabular}{lll}
\hline & & Job Satisfaction \\
\hline Nature of work (I) & Pearson Correlation & $.526^{* *}$ \\
& Sig. (2-tailed) & .000 \\
Administrative support (E) & Pearson Correlation & $.677^{* *}$ \\
& Sig. (2-tailed) & .000 \\
Relation with colleagues (E) & Pearson Correlation & $.696^{* *}$ \\
& Sig. (2-tailed) & .000 \\
Relation with supervisor (E) & Pearson Correlation & $.534^{* *}$ \\
& Sig. (2-tailed) & .000 \\
Promotion prospects (I) & Pearson Correlation & $.801^{* *}$ \\
& Sig. (2-tailed) & .000 \\
Job Security (E) & Pearson Correlation & $.539^{* *}$ \\
Autonomy (I) & Sig. (2-tailed) & .000 \\
Role in decision making (I) & Pearson Correlation & $.664^{* *}$ \\
& Sig. (2-tailed) & .000 \\
Opportunities for P.D (I) & Pearson Correlation & $.677^{* *}$ \\
& Sig. (2-tailed) & .000 \\
Student quality \& behaviour (E) & Pearson Correlation & $.553^{* *}$ \\
& Sig. (2-tailed) & .000 \\
Recognition of achievement (I) & Sig. (2-tailed) & Pearson Correlation \\
& Sig. (2-tailed) & $.752^{* *}$ \\
Pay (E) & Pearson Correlation & .000 \\
Benefits (E) & Sig. (2-tailed) & $.026^{* *}$ \\
Respect accorded by society (I) & Pearson Correlation & $.748^{* *}$ \\
& Sig. (2-tailed) & .000 \\
& Sig. (2-tailed) & .000 \\
\hline
\end{tabular}

*Correlation statistically significant at the 0.05 leve1; **Correlation statistically significant at the 0.01 level

$\mathrm{E}=$ Extrinsic Factors; I = Intrinsic Factors 
Appendix 2 - Pearson Correlation Matrix (Public Sector Teachers)

\begin{tabular}{|c|c|c|}
\hline & & Job Satisfaction \\
\hline \multirow[t]{2}{*}{ Nature of work (I) } & Pearson Correlation & $.565^{* *}$ \\
\hline & Sig. (2-tailed) & .000 \\
\hline \multirow[t]{2}{*}{ Administrative support (E) } & Pearson Correlation & $.631^{* *}$ \\
\hline & Sig. (2-tailed) & .000 \\
\hline \multirow[t]{2}{*}{ Relation with colleagues (E) } & Pearson Correlation & $.616^{* *}$ \\
\hline & Sig. (2-tailed) & .000 \\
\hline \multirow[t]{2}{*}{ Relation with supervisor (E) } & Pearson Correlation & $.574^{* *}$ \\
\hline & Sig. (2-tailed) & .000 \\
\hline \multirow[t]{2}{*}{ Promotion prospects (I) } & Pearson Correlation & $.601 * *$ \\
\hline & Sig. (2-tailed) & .000 \\
\hline \multirow[t]{2}{*}{ Job Security (E) } & Pearson Correlation & $.400^{* *}$ \\
\hline & Sig. (2-tailed) & .000 \\
\hline \multirow[t]{2}{*}{ Autonomy (I) } & Pearson Correlation & $.600^{* *}$ \\
\hline & Sig. (2-tailed) & .000 \\
\hline \multirow[t]{2}{*}{ Role in decision making (I) } & Pearson Correlation & $.513^{* *}$ \\
\hline & Sig. (2-tailed) & .000 \\
\hline \multirow[t]{2}{*}{ Opportunities for P.D. (I) } & Pearson Correlation & $.604^{* *}$ \\
\hline & Sig. (2-tailed) & .000 \\
\hline \multirow{2}{*}{$\begin{array}{l}\text { Student Quality \& behaviour } \\
\text { (E) }\end{array}$} & Pearson Correlation & $.460 * *$ \\
\hline & Sig. (2-tailed) & .000 \\
\hline \multirow[t]{2}{*}{ Recognition of achievement (I) } & Pearson Correlation & $.632^{* *}$ \\
\hline & Sig. (2-tailed) & .000 \\
\hline \multirow[t]{2}{*}{ Pay (E) } & Pearson Correlation & $.636^{* *}$ \\
\hline & Sig. (2-tailed) & .000 \\
\hline \multirow[t]{2}{*}{ Benefits (E) } & Pearson Correlation & $.499 * *$ \\
\hline & Sig. (2-tailed) & .000 \\
\hline \multirow[t]{2}{*}{ Respect accorded by society (I) } & Pearson Correlation & $.406^{* *}$ \\
\hline & Sig. (2-tailed) & .000 \\
\hline
\end{tabular}

*Correlation statistically significant at the 0.05 level; ${ }^{* *}$ Correlation statistically significant at the 0.01 level.

$$
\mathrm{E}=\text { Extrinsic Factors; } \mathrm{I}=\text { Intrinsic Factors }
$$


116 The Lahore Journal of Economics, Vol.8, No.1

\section{References}

Abd Main bin Haji Salimon 1993 Teachers Job Satisfaction and Its Relationship to Background, Curriculum and Teaching Management. Unpublished Doctoral Dissertation, University Kebangsaan Malaysia, Bangi.

Ashton, P.T., and Webb, R.B. 1986. Making A Difference: Teacher's Sense of Efficacy and Student Achievement. New York: Longmann.

Bertz, R. D. Jr., \& Judge, T. A. 1994. Person-organisation fit and the theory of work adjustment: Implications for satisfaction, tenure, and career success. Journal of Vocational Behaviour, 44(1), 32-54.

Choy, S.P., Bobbitt, S.A., Henke, R.R., Medrich, E.A., Horn, LJ., and Liberman, J. 1993. America's Teachers: Profile of a Profession. Washington, DC: U.S. Department of Education, Office of Educational Research and Improvement, National Center for Education Statistics, NCES 93-025.

Clarke, R., \& Keating, W. F. 1995. A fresh look at teacher job satisfaction. (ERIC Document Reproduction Service No. ED 391 795).

Cohen, Arthur M., Brawer, Florence B. 1982. The American Community College, San Francisco: Jossey-Bass 1982.

Cranny, C.J., Smith, P.C., \& Stone, E.F. 1992. Job Satisfaction: Advances in research and applications. NY: Free Press

Czubaj, C. A. 1996. Maintaining Teacher Motivation. Education, 116(3), $372-378$.

Fisher, C.D. 2000. Mood, and emotions while working: Missing pieces of job satisfaction? Journal of Organisational Behaviour, 21, 185202.

Frase, Larry E. 1992. Maximizing People Power in Schools: Motivating and Managing Teachers and Staff. Newbury Park, CA: Corwin Press, Inc.

Friesen, D., Holdaway, E.A., \& Rice, A.W. 1983. Satisfaction of schoo1 principals with their work. Educational Administration Quarterly, 19 (4), 35-58. 
Gibson, J. L., \& Klein, S. M. 1970, December. Employee attitudes as a function of age and length of service: A re-conceptualization. Academy of Management Journal, 13, 411-425.

Graham, J.B. 1985. Serious about keeping good teachers? Help them reclaim lost teaching time. American School Board Journal, 172, 35-36.

Gretzinger, N.K. 1992. Incentives that Maximize Teacher Motivation As Perceived by Arizona Exemplary Teachers. Unpublished Doctoral Dissertation, Northern Arizona University, Arizona.

Herzberg, F., Mausner, B., \& Snyderman, B. B. 1959. The motivation to work (2nd ed.). New York, NY: Wiley \& Sons, Inc.

Hodson, R. 1989. Gender differences in job satisfaction: Why aren't women more dissatisfied? The Sociological Quarterly, 30(3), 385-399.

Janson, P., \& Martin, J. K. 1982, June. Job satisfaction and age: A test of two views. Social Forces, 60(4), 1089-1102.

Johnson, E. D. 1967. An analysis of factors related to teacher satisfactiondissatisfaction (Doctoral dissertation, Auburn University, 1967). Dissertation Abstracts, 27, 4076A.

Kelly, J. D. 1989, Summer. Gender, pay and job satisfaction of faculty in journalism. Journalism Quarterly, 66(2), 446-452.

Lacy, A. 1968. An analysis of factors that affect job satisfaction of public high school business teachers in Ohio (Doctoral dissertation, The Ohio State University, 1968). Dissertation Abstracts International, 30, $67 A$.

Lee, R. and Wilbur, E.R. 1985. Age, Education, Job Tenure, Salary, Job Characteristics, and Job Satisfaction: A Multivariate Analysis. Human Relations, 38(8), 78, 1-791.

Lee, W.T., \& Mitche1, R.T. 1994. Organizational attachment: Attitudes and actions. In J. Greenberg (Ed.), Organisational Behaviour (pp. 83108). NJ: Lawrence Erlbaum.

Locke, E.A. 1976. The Nature and Cause of Job Satisfaction. Handbook of Industrial and Organisational Psychology.

McCaslin, V. L., \& Mwangi, J. 1994. Job satisfaction of Kenya's Rift Valley Extension agents. Journal of Extension [Online]. 32(3). 
118 The Lahore Journal of Economics, Vol.8, No.1

National Center for Education Statistics, Washington DC 1997. Job Satisfaction Among America's Teachers: Workplace Conditions, Background Characteristics and Teacher Compensation.

Ostroff, C. 1992. The Relationship Between Satisfaction, Attitudes and Performance: An Organisational Leve1 Analysis. Journal of Applied Psychology, 77: 963-974.

Peterson, Kenneth D. 1995. Teacher Evaluation: A Comprehensive Guide to New Directions and Practices, Thousand Oaks, CA, Corwin Press, Inc.

Schultz, D.P., \& Schultz, S.E. 1990. Psychology and Industry Today. New York: MacMillan.

Simmons, R. M. 1970. The measurement of factors of teacher satisfaction and dissatisfaction in teaching (Doctoral dissertation, University of Tennessee, 1970). Dissertation Abstracts International, 31, 3239A.

Sloane, P.J and Williams, H. 1996b, "Job Satisfaction, Comparison Income and Gender", Unpublished.

Spector, P.E. 1997. Job Satisfaction: Application, Assessment, Cause and Consequences, Thousand Oaks, California: Sage Publications.

Steinbach, G. M. 1979. Job reinforcers and job satisfaction among public secondary industrial arts teachers in Minnesota (Doctoral dissertation, University of Minnesota, 1979. Dissertations Abstracts International, 40, 4932A..

Varca, P.E., Shaffer, G.S., \& McCauley, C.D. 1983. Sex differences in job satisfaction revisited. Academy of Management Journal, 26(2), 348-353.

Wong, R.Y.L. 1986. The Relationship between Teachers Morale and School Climate. An Unpublished M.ED. Thesis, National University of Singapore, Singapore. 